\title{
Significance of the disulphide bonds of human growth hormone
}

\author{
Znaczenie wiązań disiarczkowych w ludzkim hormonie wzrostu
}

\author{
Riia K. Junnila, John J. Kopchick \\ Edison Biotechnology Institute, Ohio University, Athens, Ohio, United States
}

\begin{abstract}
Growth hormone (GH) structure is stabilised by two disulphide bonds, C53-C165 and C182-C189 in human GH. Researchers have investigated the role of these structural features since the late 1960s. Early studies implied that the disulphide bonds would not be important for biological activity of GH. However, more advanced techniques, as well as clues from patients carrying mutations in their GH1 gene, have demonstrated that the integrity of the disulphide bond between cysteines C53 and C165 is required for biological activity of GH. In contrast, disruption of the C-terminal disulphide bond (C182-C189) has only modest effects on the biological potency of GH, despite decreased binding affinity to $\mathrm{GH}$ receptor and reduced stability as shown by a comprehensive in vitro study.

To confirm these results, we generated transgenic mice that express a human GH analogue, C189A, and observed normal growth-promoting and lipolytic activities. In this article, we present new data and review old results concerning the disulphide bonds of GH. We also discuss relevant mutations found in patients with growth disorders. (Endokrynol Pol 2013; 64 (4): 300-304)

Key words: growth hormone, disulphides, structure-activity relationship

\section{Streszczenie}

Struktura hormonu wzrostu (GH, growth hormone) stabilizowana jest dwoma wiązaniami disiarczkowymi - C53-C165 o C182-C189 w ludzkim GH. Naukowcy badają rolę tych cech strukturalnych od końca lat 60 . ubiegłego stulecia. Początkowe badania sugerowały, że wspomniane wiązania disiarczkowe nie są istotne dla aktywności biologicznej GH. Jednak w wyniku zastosowania bardziej zaawansowanych technik badawczych, a także na podstawie danych uzyskanych u pacjentów będących nosicielami mutacji genu GH1 stwierdzono, że dla aktywności biologicznej GH konieczna jest obecność wiązania disiarczkowego między cysteiną w pozycji C53 i cysteiną w pozycji C165. Z kolei przerwanie C-końcowego wiązania disiarczkowego (C182-C189) w niewielkim zakresie wpływa na siłę działania biologicznego GH mimo stwierdzonego w kompleksowym badaniu in vitro obniżenia powinowactwa wiązania z receptorem GH i obniżenia trwałości. W celu potwierdzenia tych wyników autorzy otrzymali myszy transgeniczne, u których zachodzi ekspresja analogu ludzkiego GH C189A, i stwierdzili prawidłowe działanie pobudzające wzrost i prawidłowy wpływ na lipolizę. W niniejszej pracy przedstawiamy nowe dane i przegląd dotychczasowych danych na temat wiązań disiarczkowych w GH. Omawiany też istotne mutacje stwierdzane u pacjentów z zaburzeniami wzrastania. (Endokrynol Pol 2013; 64 (4): 300-304)
\end{abstract}

Słowa kluczowe: hormon wzrostu, disiarczki, związek pomiędzy strukturą i aktywnością

JJK is supported by the State of Ohio's Eminent Scholar Programme which includes a gift from Milton and Lawrence Goll, by AMVETS, and by NIH (PO1AG031736). Generation of transgenic mice was supported by an Ohio University Baker Award.

\section{Introduction}

Knowledge about the structure-function relationships of growth hormone (GH) helps to understand how a specific gene mutation could be associated with a patient's phenotype. The overall structure of GH is stabilised by two disulphide bonds that are conserved across species. Corresponding disulphide bonds are also found in other members of the GH family. Mutations identified in patients with retarded growth as well as a handful of in vitro and in vivo studies have helped to establish the role of these disulphide bonds in normal GH action. Issues associated with
GH's disulphide bonds as they relate to GH action are described below.

\section{GH structure}

A GH molecule consists of four alpha-helices that are organised in an up-up-down-down manner [1]. The GH structure is stabilised by two disulphide bonds; C53C165 links the crossover connection between helices I and II to helix IV, and C182-C189 forms a small loop in the C-terminus (Fig. 1) [2]. GH binds to a pre-dimerised GH receptor (GHR) via two binding sites: a high-affinity binding site 1 and a low-affinity binding site $2[1,3]$. 


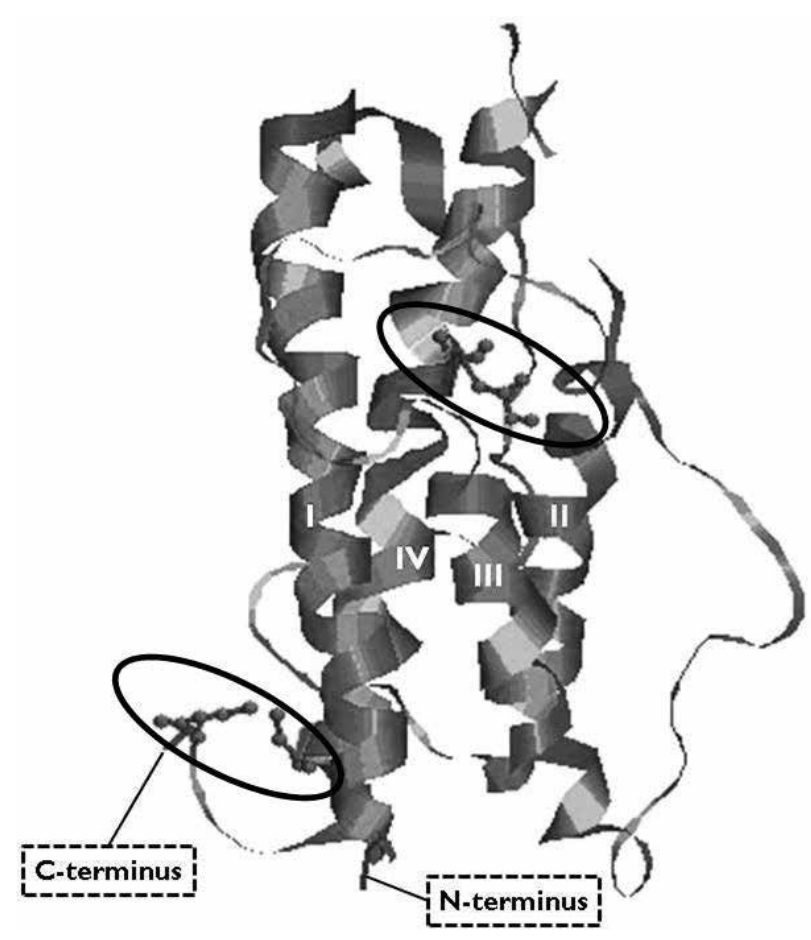

Figure 1. Location of disulphide bonds in a GH molecule. Protein Data Bank entry 1HGU [2] was modelled with RasMol Version 2.4.7.2 (RasWin Molecular Graphics). Helices I, II, III, and IV as well as position of disulphide bonds are indicated

Rycina 1. Umiejscowienie wiąań disiarczkowych w cząsteczce GH. Hasto "1HGU" zawarte w Protein Data Bank [2] poddano modelowaniu z użyciem programu RasMol w wersji 2.4.7.2 (RasWin Molecular Graphics). Na rycinie wskazano helisy I, II, III i IV oraz pozycję wiazan disiarczkowych

The C-terminal disulphide bond is involved in site 1 binding, whereas C53-C165 is not in close proximity to either binding site [4].

\section{Disulphide bonds}

Disulphide bonds, or simply disulphides, are formed between two cysteine molecules through oxidation of their thiol groups. In eukaryotic cells, the endoplasmic reticulum (ER) is the main site for disulphide bond formation, but this reaction also occurs in the mitochondria [5]. Disulphide bonds can be formed spontaneously but, in vivo, the reaction is usually catalysed by enzymes, such as the protein disulphide isomerases in the ER [6,7]. Disulphide bonds are important stabilisers of a protein's structure but they also have a role in facilitating protein folding [6, 7].

\section{The GH family}

The two disulphide bonds found in GH are conserved across species and also present in other members of the GH family. The GH gene cluster on chromosome 17 in humans contains genes for the 'normal', pituitary- -derived GH(GH1 or GH-N), the placental GH variant (GH2 or $G H-V$ ) and three placental lactogens (PL); $C S-A$ and CS-B (or CSH1 and CSH2) encode the same polypeptide whereas the product of $C S-L$, a shorter variant, has not been detected on protein level $[8,9]$. The gene encoding prolactin (PRL), another member of the GH family, is located on chromosome 6 in humans. PRL gene diverged from the other $\mathrm{GH}$ family genes $\sim 400$ million years ago [10], and the mature protein shares $24 \%$ amino acid sequence identity with GH [11]. Genes of the GH cluster diverged $\sim 10$ million years ago [10]. Placental GH shares 93\% and PL 86\% amino acid sequence identity with pituitary GH [11]. For comparison, cow and man diverged $\sim 75$ million years ago [12] and they are $66 \%$ identical in their amino acid sequence [11]. All the aforementioned proteins contain two disulphide bonds similar to those in human GH [13-16]. PRL, the most distant relative, has an additional disulphide bond in its N-terminus [15].

\section{Clinical significance}

Heterozygous deletion of exon 3 of the GH1 gene, which leads to deletion of amino acids 32-71, causes isolated GH deficiency type II and subsequent short stature. The dominant negative effect is due to impaired GH secretion caused by the truncated GH [17]. Deletion of exon 3 disrupts the disulphide bond between C53C165 and leaves an 'unpaired' cysteine. However, since another GH1 mutation, C53S, does not display a dominant negative effect, it is not likely that the unpaired C165 would be responsible for the defective secretion. C53S causes short stature only in the homozygous state and is found in circulation at rather high levels (basal $13.5 \mathrm{ng} / \mathrm{mL}$, peak after ITT $44.7 \mathrm{ng} / \mathrm{mL}$ ) [18]. In vitro studies regarding exon 3 deletion and the C53S analogue are discussed in the following section.

Mutations that alter the C-terminal disulphide bond are less common. A C182R substitution has been reported in a patient with hypertension in a study that also found an inverse correlation between adult height and central hypertension [19]. Unfortunately, the height of the patient carrying the C182R mutation was not reported. In a recent meeting of the $\mathrm{GH}$ and IGF-1 research societies (Munich, Germany, 2012), a heterozygous deletion mutation that results in disruption of the C-terminal disulphide bond was reported to be associated with short stature, but the case report has not yet been published. In addition to the mutations that disrupt the disulphide bonds of $\mathrm{GH}$, a few mutations that introduce a fifth cysteine have been reported in patients with short stature $[20,21]$. Such mutations could interfere with formation of native disulphide bonds or lead to intermolecular disulphide bonding. Free cysteines could also affect protein stability. 


\section{Early research}

Several papers described the significance of the GH's disulphide bonds even before publication of the GH cDNA sequence, production of recombinant GH or determination of its crystal structure. In 1966, it was reported that human pituitary $\mathrm{GH}$, when exposed to a rather harsh reduction and alkylation process using urea, mercaptoethanol, methylamine and iodoacetamide, still retained most of GH's action [22]. Biological activity of the modified GH was examined by rat tibia (diameter) and pigeon crop sac growth tests. The authors reported that the reduced and alkylated GH retained full potency, although a trend of lower bioactivity was seen in the pigeon crop sac test [22]. In a 1969 report, the use of dithiothreitol allowed a more gentle reduction of disulphide bonds without a denaturant [23]. After reduction, GH was either carboxymethylated (CXY-GH) or carbamidomethylated (CAM-GH). CXY$\mathrm{GH}$ exhibited reduced biological activity in both the rat tibia and pigeon crop sac tests, whereas bioactivity of CAM-GH was unchanged. CXY-GH was also much more susceptible to trypsin digestion. The low stability of GH under these conditions explained the reduced bioactivity, and the authors concluded that disulphide bonds do not otherwise contribute to the biological activity of GH [23]. Additionally, CAM-GH was tested in $\mathrm{GH}$-deficient prepubertal males and found to induce the same metabolic changes as unmodified GH [24].

Later structure-function studies showed that, compared to native GH, both CAM-GH and CXY-GH have reduced immunoreactivity in radioimmunoassay as well as lower binding affinity to GHR using a radioreceptor assay. However, their conformation did not differ from unmodified $\mathrm{GH}$ when analysed by circular dichroism spectrum [25].

Graf et al. were the first to specifically investigate the C-terminal disulphide bond [26]. They selectively reduced and alkylated either both $\mathrm{GH}$ disulphide bonds or only the C-terminal one. C-terminally carboxymethylated GH showed the same biological activity in rat tibia and pigeon crop sac tests as unaltered $\mathrm{GH}$, whereas the fully carboxymethylated GH displayed decreased activity in both tests - in accordance with the studies using CXY-GH described above $[23,25,26]$.

\section{Site-directed mutagenesis}

Advances in biotechnology have allowed manipulations at the DNA level such that chemical modifications are no longer needed for disruption of disulphide bonds. A C165A mutation was introduced into $\mathrm{GH}$, disrupting the disulphide bond between C53 and C165 [27]. This $\mathrm{GH}$ analogue was expressed in $E$. coli at levels equal to wildtype (wt) GH (measured by radioimmunoassay) and displayed a similar digestion pattern with human plasmin enzyme, indicating a similar tertiary structure. Treatment of hypophysectomised rats with the GHC165A analogue had the same effect on growth as wt $\mathrm{GH}$ [27]. Another study analysed a wider variety of GH analogues: C53A, C53A+C165A, C53A+C165S, C165S and C165A [28]. They were expressed in E. coli and their bioactivity was determined by effect on differentiation of 3T3-F442A cells into adipocytes. Binding affinity to GHR was assessed by radioreceptor assay. The biological activity of all the GH analogues was decreased, and the differences to wt GH did not seem to depend on the number of cysteines mutated or whether the cysteine was replaced with serine or alanine. Binding affinity of the $\mathrm{GH}$ analogues was approximately half of that of the wt GH [28].

In order to investigate differences in the roles of the two disulphide bonds of $\mathrm{GH}$, cysteines of bovine $\mathrm{GH}(\mathrm{bGH})$ were replaced with serines, generating bGH analogues C53S, C164S, C53S+C164S, C181S, C189S and C181S+C189S [29]. Previous studies concerning the disulphide bonds in GH had been conducted in human $\mathrm{GH}$, thus it was also of interest to find differences between bovine and human GH. Expression of the bGH analogues in mouse L-cells showed that the disruption of the disulphide bond between C53 and C164 resulted in drastically decreased GH secretion. Also C181S + C189S showed reduced secretion but C181S and C189S analogues were secreted normally. These two analogues were further studied in regard to binding affinity to GHR. Both analogues displayed reduced binding affinity, but the change was much more prominent for C181S [29]. A previous study had shown that a C182A mutation reduces receptor binding affinity of human GH. C189A could not be analysed in that study due to low production in E. coli [30]. Several bovine GH analogues were also expressed in transgenic mice [29]. Growth of mice expressing C53S, C53S+C189S, C164S and C164S + C181S did not differ from that of nontransgenic mice, indicating that these analogues lack biological activity. On the other hand, mice expressing C181S or C189S analogues showed similar enhanced growth as mice expressing wt bGH [29].

\section{The new millennium}

In order to bring understanding to the dominant negative effect seen in patients with mutations that cause skipping of GH1 exon 3 (aa 32-71), Iliev et al. [31] deleted different fractions of exon 3 and performed site-directed mutagenesis to disrupt the disulphide bond between C53 and C165. Co-secretion with wt GH was studied in somatotroph-derived rat $\mathrm{GH}_{4} \mathrm{C}_{1}$ cells. The authors 
concluded that the mutations that only affected the C53-C165 disulphide bond were not sufficient to impair secretion, although a minor inhibitory effect on wt $\mathrm{GH}$ secretion was observed. Size of the deletion was a more important factor [31].

Following the identification of the homozygous C53S mutation in a patient with short stature, Besson et al. characterised this $\mathrm{GH}$ analogue in vitro [18]. The $\mathrm{GH}$ analogue was expressed in Chinese hamster ovary cells, after which it was characterised regarding binding affinity and ability to activate the Jak/STAT pathway, the major signalling cascade activated by GH. An immunofunctional assay that measures the integrity of both receptor binding sites [32] showed that the binding sites of GH analogue C53S were barely functional. Also, results from radioreceptor assay indicated a significantly reduced binding affinity to GHR. Consequently, this GH analogue also displayed a decreased bioactivity [18].

Motivated by a human mutation affecting the Cterminal disulphide bond [unpublished data], Junnila et al. [11] performed an array of in vitro experiments in order to more closely characterise the importance of the C182-C189 disulphide bond. GH analogues C182A, C189A and C182A+C189A were expressed in human embryonic kidney cells. All GH analogues showed a significantly decreased GHR binding affinity, but only the C189A analogue also displayed a reduced biological activity in a cell proliferation assay compared to wt GH. C182A and C189A induced less STAT5 activation than wt and showed decreased stability. C182A+C189A was most similar to wt $\mathrm{GH}$, indicating that a free cysteine affects GH activity more than the absence of its C-terminal disulphide bond [11].

As a follow-up to the aforementioned study, transgenic mice expressing the human $\mathrm{GH}$ analogue C189A - the one with lowest binding affinity and bioactivity - were generated. These mice display a 'giant' phenotype (see Fig. 2) similarly to the mice expressing bGH C189S [29]. Body composition of transgenic mice expressing human $\mathrm{GH}$ analogue C189A (Fig. 3) resembles that of wt bGH transgenic mice: increased lean mass combined with a reduced fat mass [33]. Thus, despite the decrease in bioactivity seen in vitro, these mice show that the GH analogue C189A has high potency to induce growth and to mediate lipolytic effects in vivo.

\section{Conclusions}

Studies since the 1960s have attempted to elucidate the significance of GH's disulphide bonds as it relates to the biological actions of GH. Early studies may have suffered from the harsh chemical treatments required for reduction of the disulphide bonds; yet, biological

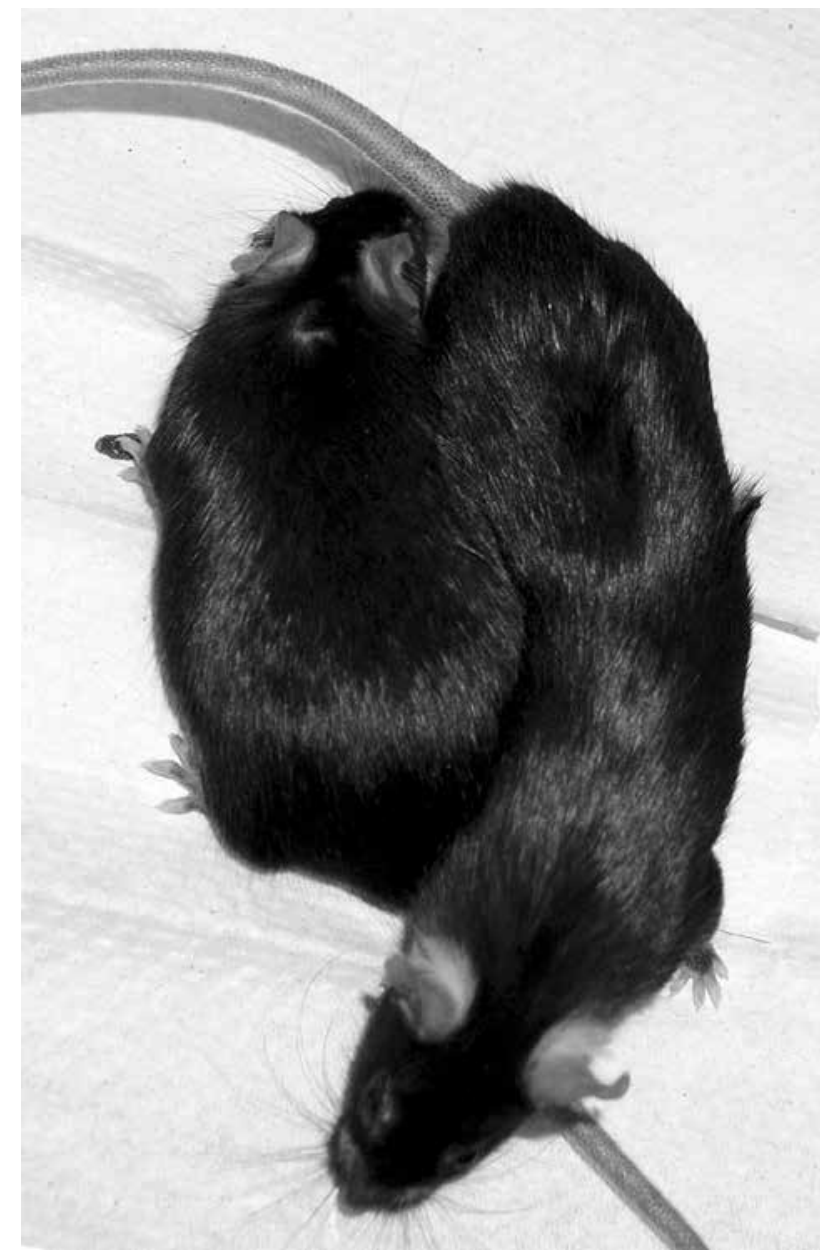

Figure 2. Female wt (left) and GH C189A transgenic littermate (right) at ten months of age. At this age, weight of the transgenic mouse was $48 \mathrm{~g}$ and that of the wt mouse $36 \mathrm{~g}$

Rycina 2. Samica myszy dzikiego typu (po lewej) i pochodząca z tego samego miotu mysz transgeniczna GH C189A (po prawej) w wieku 10 miesięcy. W tym wieku masa ciała myszy transgenicznej wynosita $48 \mathrm{~g}$, a myszy dzikiego typu $36 \mathrm{~g}$

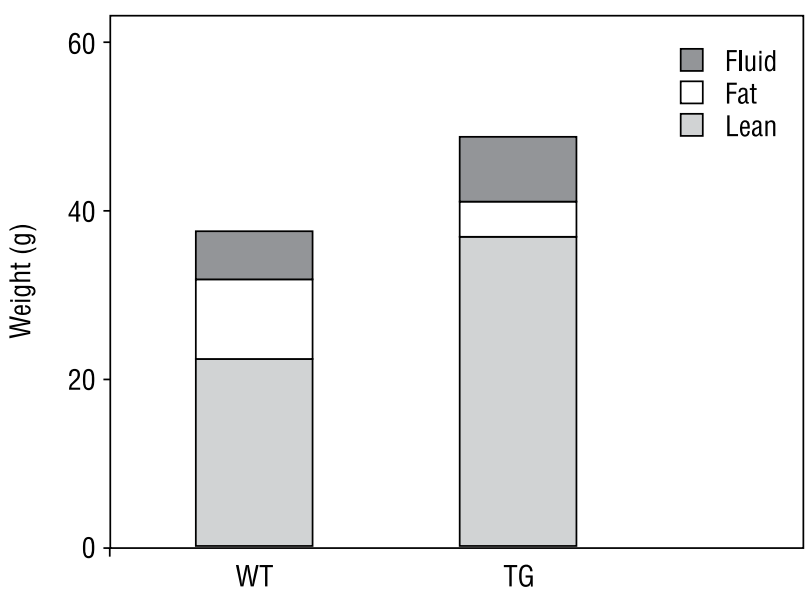

Figure 3. Body composition of ten-month-old GH C189A transgenic (tg) mouse vs. wt mouse

Rycina 3. Skład ciała 10-miesięcznej myszy transgenicznej GH C189A (TG) i myszy typu dzikiego (WT) 
potency remained unchanged. This could be due to difficulties in achieving complete reduction of the disulphide bonds. Also, the tests for biological potency were not as sophisticated as they are today. The early studies did show that the disulphide bonds are important for protein stability, and the least stable forms of $\mathrm{GH}$ also displayed lower biological activity than intact $\mathrm{GH}$ [23]. A recent in vitro study focusing on the C-terminal disulphide bond observed a small decrease in biological activity despite loss of stability due to C182A or C189A mutations. Substituting both cysteines with alanines, generating $\mathrm{GH}$ analogue $\mathrm{C} 182 \mathrm{~A}+\mathrm{C} 189 \mathrm{~A}$, returned the stability to a normal level [11]. This indicates that the decreased stability is due to the unpaired cysteine and not absence of the C-terminal disulphide bond. To confirm this hypothesis, it would be of interest to perform similar tests with the disulphide bond between C53 and C165.

Transgenic mice that express human GH analogue C189A display a giant and lean phenotype - similar to mice expressing wt bovine $\mathrm{GH}$. These mice provide further evidence that human GH with a disrupted Cterminal disulphide bond has full biological potency. This is somewhat surprising since the mutation changes the conformation at the high-affinity binding site 1 and the $\mathrm{GH}$ analogue $\mathrm{C} 189 \mathrm{~A}$ had shown reduced binding affinity to GHR and decreased biological activity in in vitro studies.

In summary, integrity of the C-terminal disulphide bond (C182-C189) is required for optimal binding to GHR and for normal stability, but not for biological activity. In contrast, the disulphide bond between C53 and C165 is necessary for full biological activity of the hormone, indicating that it is more than a merely supporting structure.

\section{References:}

1. de Vos AM, Ultsch M, Kossiakoff AA. Human growth hormone and extracellular domain of its receptor: crystal structure of the complex. Science 1992; 255: 306-312.

2. Chantalat L, Jones ND, Korber F et al. The crystal-structure of wildtype growth-hormone at 2.5 angstrom resolution. Protein Pept Lett 1995; 2: 333-340.

3. Sundstrom M, Lundqvist T, Rodin J et al. Crystal structure of an antagonist mutant of human growth hormone, G120R, in complex with its receptor at 2.9 A resolution. J Biol Chem 1996; 271: 32197-32203.

4. Cunningham BC, Ultsch M, De Vos AM et al. Dimerization of the extracellular domain of the human growth hormone receptor by a single hormone molecule. Science 1991; 254: 821-825.

5. Riemer J, Bulleid N, Herrmann JM. Disulfide formation in the ER and mitochondria: two solutions to a common process. Science 2009; 324: 1284-1287.
6. Feige MJ, Hendershot LM. Disulfide bonds in ER protein folding and homeostasis. Curr Opin Cell Biol 2011; 23: 167-175.

7. Oka OB, Bulleid NJ. Forming disulfides in the endoplasmic reticulum. Biochim Biophys Acta 2013 (epub)

8. Chen EY, Liao YC, Smith DH et al. The human growth hormone locus: nucleotide sequence, biology, and evolution. Genomics 1989; 4: 479-497.

9. Ho Y, Liebhaber SA, Cooke NE. Activation of the human GH gene cluster: roles for targeted chromatin modification. Trends Endocrinol Metab 2004; 15: 40-45.

10. Cooke NE, Coit D, Shine J et al. Human prolactin. cDNA structural analysis and evolutionary comparisons. J Biol Chem 1981; 256: 4007-4016.

11. Junnila RK, Wu Z, Strasburger CJ. The role of human growth hormone's C-terminal disulfide bridge. Growth Horm IGF Res 2013 (epub).

12. Forsyth IA, Wallis M. Growth hormone and prolactin--molecular and functional evolution. J Mammary Gland Biol Neoplasia 2002; 7: 291-312.

13. Igout A, Scippo ML, Frankenne F et al. Cloning and nucleotide sequence of placental hGH-V cDNA. Arch Int Physiol Biochim 1988; 96: 63-67.

14. Walsh ST, Kossiakoff AA. Crystal structure and site 1 binding energetics of human placental lactogen. J Mol Biol 2006; 358: 773-784.

15. Teilum K, Hoch JC, Goffin V et al. Solution structure of human prolactin. J Mol Biol 2005; 351: 810-823.

16. Miller WL, Martial JA, Baxter JD. Molecular cloning of DNA complementary to bovine growth hormone mRNA. J Biol Chem 1980; 255: 7521-7524.

17. Mullis PE. Genetics of growth hormone deficiency. Endocrinol Metab Clin North Am 2007; 36: 17-36.

18. Besson A, Salemi S, Deladoey J et al. Short stature caused by a biologically inactive mutant growth hormone (GH-C53S). J Clin Endocrinol Metab 2005; 90: 2493-2499.

19. Horan M, Newsway V, Yasmin et al. Genetic variation at the growth hormone (GH1) and growth hormone receptor (GHR) loci as a risk factor for hypertension and stroke. Hum Genet 2006; 119: 527-540.

20. Takahashi Y, Kaji H, Okimura Y et al. Brief report: short stature caused by a mutant growth hormone. N Engl J Med 1996; 334: 432-436.

21. Millar DS, Lewis MD, Horan M et al. Novel mutations of the growth hormone 1 (GH1) gene disclosed by modulation of the clinical selection criteria for individuals with short stature. Hum Mut 2003; 21: $424-440$

22. Dixon JS, $\mathrm{LiCH}$. Retention of the biological potency of human pituitary growth hormone after reduction and carbamidomethylation. Science 1966; 154: 785-786.

23. Bewley TA, Brovetto-Cruz J, Li CH. Human pituitary growth hormone physicochemical investigations of the native and reduced-alkylated protein. Biochemistry 1969; 8: 4701-4708.

24. Connors $\mathrm{MH}$, Kaplan SL, Li CH et al. Retention of biologic activity of human growth hormone in man after reduction and alkylation. J Clin Endocrinol Metab 1973; 37: 499-504.

25. Aubert ML, Bewley TA, Grumbach MM et al. Structure-function studies on human growth hormone. Int J Peptide Protein Res 1986; 28: 45-57.

26. Graf L, Borvendeg J, Barat E et al. Reactivity and biological importance of the disulfide bonds in human growth hormone. FEBS Lett 1976; 66: 233-237.

27. Tokunaga T, Tanaka T, Ikehara M et al. Synthesis and expression of a human growth hormone (somatotropin) gene mutated to change cysteine-165 to alanine. Eur J Biochem 1985; 153: 445-449.

28. Uchida E, Uemura H, Tanaka T et al. Activity of artificial mutant variants of human growth hormone deficient in a disulfide bond between Cys53 and Cys165. Chem Pharm Bull 1991; 39: 150-153.

29. Chen XZ, Shafer AW, Yun JS et al. Conversion of bovine growth hormone cysteine residues to serine affects secretion by cultured cells and growth rates in transgenic mice. Mol Endocrinol 1992; 6: 598-606.

30. Cunningham BC, Wells JA. High-resolution epitope mapping of hGHreceptor interactions by alanine-scanning mutagenesis. Science 1989; 244: 1081-1085.

31. Iliev DI, Wittekindt NE, Ranke MB et al. Structural analysis of human growth hormone with respect to the dominant expression of growth hormone $(\mathrm{GH})$ mutations in isolated GH deficiency type II. Endocrinology $2005 ; 146$ : 1411-1417.

32. Strasburger CJ. Methods in determining growth hormone concentrations: an immunofunctional assay. Pediatrics 1999; 104: 1024-1028.

33. Palmer AJ, Chung M-Y, List EO et al. Age-related changes in body composition of bovine growth hormone transgenic mice. Endocrinology 2009; 150: 1353-1360. 